\title{
World Markets for Organic Fruits and Vegetables ${ }^{1}$
}

James J. Ferguson ${ }^{2}$

Increasing sales of organic foods, changes in dietary habits, major food safety concerns, and greater personal health awareness have led to greater consumer interest in documentation of production practices for fresh fruits and vegetables, especially for certified organic crops. Since international Customs agencies and related trade and regulatory agencies do not now distinguish between conventionally grown and organic produce, reliable data are not readily available on market development and international trade of organically grown fresh fruits and vegetables. Accordingly, Pascal Liu and others at the International Trade Center, Food and Agriculture Organization (FAO) of the United Nations, reviewed available literature, conducted surveys and interviewed key players in international organic marketing in 2000 for a report entitled "World Markets for Organic Fruit and Vegetables Opportunities for Developing Countries in the Production and Export of Organic Horticultural Products."

The full text of this report is available at http://www.fao.org/docrep/004/y1669e/ y1669e00.htm\#Contents. To emphasize the breath and depth of this report, I have listed the contents and have summarized the main findings in this fact sheet, much of the material for which has been taken directly or indirectly from this FAO report. Hopefully, this information will aid Florida organic fruit and vegetable growers and others in assessing their export potential for European and Japanese markets.

Topics in the FAO report include:

- Findings and Identified Opportunities for Developing Countries

- Requirements for Producing and Exporting Organic Produce to Major Markets

- Main Markets for Organic Fruit and Vegetables in Developed Countries (each country report is 20-30 pages): Austria, Belgium, Denmark, France, Germany, Italy, Japan, The Netherlands, Sweden, Switzerland, United Kingdom, United States

- Case Studies of Countries Producing and Exporting Organic Fruits and Vegetables (each country report is 20-30 pages): Argentina, Cameroon, Chile, Dominican Republic, Madagascar, Papua New Guinea, Zambia

1. This document is HS977, one of a series of the Horticultural Sciences Department, Florida Cooperative Extension Service, Institute of Food and Agricultural Sciences, University of Florida. Publication date: May 2004. Please visit the EDIS Web site at http://edis.ifas.ufl.edu.

2. James J. Ferguson, professor, Horticultural Sciences Department, Cooperative Extension Service, Institute of Food and Agricultural Sciences, University of Florida, Gainesville, 32611.

The Institute of Food and Agricultural Sciences (IFAS) is an Equal Employment Opportunity - Affirmative Action Employer authorized to provide research, educational information and other services only to individuals and institutions that function without regard to race, creed, color, religion, age, disability, sex, sexual orientation, marital status, national origin, political opinions or affiliations. For information on obtaining other extension publications, contact your county Cooperative Extension Service office. Florida Cooperative Extension Service / Institute of Food and Agricultural Sciences / University of Florida / Larry R. Arrington, Interim Dean 


\section{FAO Assistance to Developing Countries in Organic Agriculture}

Within each of these above market and case studies, topics covered include:

- organic production figures

- government policy

- marketing and sales data

- premiums for organic products

- distribution channels

- trends and attitudes

- market growth

- constraints to market development

- market access

- import data

- major suppliers and products

- market characteristics

- strategies and recommendations for export development

- references

- listings of importers

- organic farmer organizations

- organic certification bodies

- trade and governmental organizations

FAO has focused on encouraging sustainable agriculture and rural development by building partnerships in developing countries such as Asia, Africa, the Mediterranean and the Caribbean and national and international research centers, national organic programs, and other institutions. This assistance includes web-based material, institutional support, policy advice, field projects, training, and research. A series of case studies on the following topics, some of which may be of interest to Florida growers, provided technical information on production requirements and marketing opportunities:

- The Potential Contribution of Organic Agriculture to Sustainability

- Markets for Organic and Fair Trade Bananas

- A Socio-Ecological Analysis of Opportunities and Constraints of Organic Agriculture

- Food Safety and Quality of Organic Products

- Factors Influencing Organic Agriculture Policies, Especially in Developing Countries

- Spices and Medicinals as Bioactive Protectants for Grains

- Cost-Benefit Analysis of Organic Versus Conventional Production

- Organic Pastures and Feed

- Processing of Organic Fruits and Vegetables

These reports are listed and can be accessed at http://www.fao.org/organicag/faodoc-e.htm.

\section{Opportunities for Developed Countries}

The USA had the highest level of organic food sales in 2000, followed by Germany, the United Kingdom (primarily England, Scotland, Wales, and Northern Ireland) and Italy. Belgium, Austria, and Sweden had the lowest sales. Organic fruits and vegetables had a higher proportional share of the total fruit and vegetable market than organic crops generally had of the overall food market. Organic fruit sales were estimated at 3-5 percent of total market share in developed countries but vegetable sales were greater than 10 percent of overall vegetable sales in countries like the UK and Switzerland. Denmark had perhaps the highest organic share (2.5 - 3\%) of a domestic food market, followed by Switzerland, Austria, Germany and the USA. When only fruit and vegetable sales are considered, the United Kingdom, Austria, and Switzerland led other developed countries with the highest percentage of organic fruits and vegetables 
consumed in terms of total consumption of these commodities (Table 1).

Sales of organic fruits and vegetables increased 20-30\% annually during the 1990s, especially in countries like Italy where mad cow disease was detected in 2001, triggering a surge in overall fruit and vegetable sales and a greater than $85 \%$ increase in organic produce, generally. On the other hand, sales in Austria and Denmark, with well established organic markets and organic market share, showed little if any growth.

Supermarkets were the fastest growing organic sales outlet in most countries studied in 2000 but their marketing position varied in different countries, with approximately 70 percent of all organic sales in the UK, Switzerland and Denmark handled by supermarkets but only 20 to 30 percent handled by supermarkets in Germany, the Netherlands, Austria, and France. The authors of this study note that although the European Union (EU) has been integrating markets and organic regulations, a uniform EU market for organic fruits and vegetables has not been clearly defined. Potential exporters to these markets should therefore pay careful attention to market differences, trends, consumer profiles, and distribution channels in targeted market countries.

\section{Organic Production in Developed Countries}

Among developed countries, Italy had the greatest area in current organic production, with 2,570,772 acres, followed by the USA with 1,368,934 acres (Table 2). According to this report, southern Argentina has huge production potential with an estimated 3 million hectares (7,413,000 acres), already certified organic. However, 99 percent of this acreage is cattle pasture and some land is not in production at all. Wheat, sugar cane, fruits and vegetables are produced on the remaining 1 percent, about 60,000 acres. Other estimates of world wide organic acreage should also be examined carefully in assessing production potential. For example, Table 3, from an online publication by the International Federation of Organic Agriculture Movements, lists almost 22 million hectares (54,362,000 acres) under organic management in 2002, including 10.5 million hectares (26 million acres) in Australia and 3.2 million hectares (7,907,200 acres) in Argentina. Extensive grazing land in these countries, especially under dry land conditions, can support large livestock operations but may not be suitable for horticultural crop production. Uncultivated woodlands and other wild areas from which wild plants are harvested are also included in estimates of organic acreage.

The USDA formalized National Organic Standards in 2003, partially subsidizes organic certification costs, and sponsors sustainable and organic farming research. However, the authors of this FAO report indicated that most countries in western Europe have stronger, more specific governmental policy and financial support to encourage growers to convert to organic farming, with some countries targeting as much as a 10 percent of all farmland for organic production by 2010 .

Demand for fresh organic produce is expected to exceed supply in developed countries, but already established consumer preferences may limit the growth of imported organic produce. For example, in virtually all countries surveyed, consumers distrusted the authenticity of imported organic produce. In Switzerland the domestic organic label, Bio Suisse, actually prohibits air transport of organic products. Austrians prefer domestic produce bought at the farm and tend to purchase imported organic produce only during the off season when local produce may not be available. Surveys in Denmark indicate that consumer confidence in imported organic produce decreased with geographical distance from Denmark. In the USA and Japan, consumers prefer locally grown produce. However in some countries like the UK and Belgium where domestic production can not match demand, consumers do not readily discriminate between domestic and imported produce.

Clearly, those countries exporting organic produce to developed countries must gain buyers' confidence by working closely with organic importers, wholesalers, and retailers, even by using the domestic organic label, if possible, to encourage consumer acceptance. Some marketing trends observed in the survey included small supermarkets that sell only organic produce; biodegradable packaging; convenience organic foods like 
pre-packaged salads; internet sales; organic food sales through public canteens, and catering.

Complete farm gate, $\mathrm{fob}^{3}$, and retail prices are generally not available partially because traders who dominate markets may consider this proprietary information. However, as markets become more competitive and transparent, pricing information may become more available and the differential between organic and conventional produce may decrease, depending on supply and demand. Produce prices vary widely over time and by location, with organic produce sometimes selling between 20 to 40 percent higher than conventional produce. Lacking a complete price series, potential producers and exporters of organic fruits and vegetables should cautiously examine potential future market supply and demand and consider near term organic fresh and processed fruit and vegetable production capacity of countries like Argentina and Brazil.

\section{Developing Countries}

Domestic production of organic produce in developing countries is expected to increase but may not be able to supply local or regional demand, with the best export market opportunities in off-season fresh temperate-zone produce and non-temperate zone produce. Countries with Mediterranean climates like Italy, Spain, Israel, Morocco, and Egypt will have a geographical and in-house EU advantage in supplying EU temperate zone countries with tropical and subtropical produce compared with non-EU producers like the USA, except for off-season produce. Developing countries may also have to develop competitive producer and fob prices and a greener fresh produce export image while continuing to improve crop quality, phytosanitary and organic standards, post-harvest handling procedures, and importer/marketer/trade relations.

With supermarkets being the fastest growing sales outlet for organic produce in developed countries, organic producers in developing countries may have to adapt to the purchasing strategies and standards of buyer-driven global commodity chains, including requirements for continual supplies, price, quality, delivery, food safety, and related issues.

\section{Related Topics}

Other related FAO publications on the following topics can be accessed at http://www.fao.org/organicag/faodoc-e.htm.

World Markets for Organic Citrus and Citrus Juices: Current Market Situation and Medium -Term Prospects (May, 2003)

Economic and Financial Comparison of Organic and Conventional Citrus Growing [in Spain]

(November, 2001)

Handling and Processing of Organic Fruits and Vegetables in Developing Countries (September, 2002)

The International Federation of Organic Agriculture Movements

The World of Organic Agriculture 2003 Statistics and Future Prospects http://www.soel.de/inhalte/publikationen/s/s_74.pdf

\section{Additional Notes:}

3. F.O.B. (Free on Board) - The prices of goods on board the specified vessel at the specified port of shipment. If you have quoted F.O.B. prices, you are responsible for the shipment until it is loaded on board. 
Table 1. Value and shares of international organic markets in 2000 (average 2000 exchange rates). Missing data were not available.

\begin{tabular}{|c|c|c|c|c|}
\hline Country & $\begin{array}{c}\text { Estimated value } \\
\text { of total organic } \\
\text { sales } \\
\text { (\$ million) } \\
\end{array}$ & $\begin{array}{c}\text { Estimated share of } \\
\text { organic in total } \\
\text { food sales } \\
(\%)\end{array}$ & $\begin{array}{c}\text { Value of organic } \\
\text { fruit and vegetable } \\
\text { sales } \\
(\$ \text { million }) \\
\end{array}$ & $\begin{array}{c}\text { Estimated share of } \\
\text { organic in total fruit (F) } \\
\text { and Vegetable (V) sales } \\
(\%)\end{array}$ \\
\hline Austria & 195 & 1.8 & 29 & $3 \mathrm{~F}$ and $5 \mathrm{~V}$ \\
\hline Belgium & 138 & 1 & 34 & - \\
\hline Denmark & 372 & $2.5-3.0$ & - & - \\
\hline France & 846 & 1 & 169 & - \\
\hline Germany & 2,128 & $1.25-1.5$ & 378 & 2.6 \\
\hline Italy & 978 & 1 & 264 & 2 \\
\hline Japan & 350 & - & - & - \\
\hline Netherlands & 210 & 1.2 & - & - \\
\hline Sweden & 175 & 0.9 & 31 & 1.7 \\
\hline Switzerland & 457 & 2 & - & $5 \mathrm{~F}$ and $10 \mathrm{~V}$ \\
\hline United Kingdom & 986 & 1 & 300 & $5-10$ \\
\hline USA & 8,000 & 1.5 & 1,450 & - \\
\hline
\end{tabular}

Source: World Markets for Organic Fruit and Vegetables at http://www.fao.org/DOCREP/004/Y1669E/Y1669E00.HTM

Table 2. Organic area under production in 2000.

\begin{tabular}{|c|c|c|c|c|c|}
\hline \multirow[t]{2}{*}{ Country } & \multicolumn{2}{|c|}{ Area } & \multirow[t]{2}{*}{$\begin{array}{l}\text { Percent of total } \\
\text { production area }\end{array}$} & \multicolumn{2}{|c|}{$\begin{array}{c}\text { Organic fruit and vegetable } \\
\text { production area }\end{array}$} \\
\hline & ha & acres & & ha & acres \\
\hline Austria & 272,000 & 672,112 & & & \\
\hline Belgium & 20,663 & 51,058 & 0.9 & 612 & 1,512 \\
\hline Denmark & 165,258 & 408,353 & 6.2 & 1,912 & 4,725 \\
\hline France & 371,000 & 916,741 & 1.3 & 27,945 & 69,052 \\
\hline Germany & 546,023 & $1,349,223$ & 3.2 & 7,118 & 17,584 \\
\hline Italy & $1,040,377$ & $2,570,772$ & - & - & - \\
\hline Japan & 1,000 & 2,471 & 0.02 & - & - \\
\hline Netherlands & 27,820 & 68,743 & 1.4 & 2,100 & 5,189 \\
\hline Sweden & 139,000 & 343,469 & 5.1 & 2,300 & 5,683 \\
\hline Switzerland & 95,000 & 234,745 & 9.0 & 1,238 & 3,059 \\
\hline United Kingdom & 472,500 & $1,167,548$ & 2.5 & 3,000 & 7,143 \\
\hline USA & 544,000 & $1,368,934$ & 0.2 & 41,266 & 101,968 \\
\hline
\end{tabular}


Table 3. Land area under organic management (SOEL-Survey, February 2003).

\begin{tabular}{|c|c|c|}
\hline Country & Organic Hectares & Organic Acres \\
\hline Argentina & $3,192,000$ & $7,887,432$ \\
\hline Australia & $10,500,000$ & $25,945,500$ \\
\hline Austria & 285,500 & 705,470 \\
\hline Azerbaijan & 2,500 & 6,177 \\
\hline Belgium & 22,410 & 55,375 \\
\hline Belize & 1,810 & 4,472 \\
\hline Benin & 81 & 200 \\
\hline Bolivia & 19,634 & 48,515 \\
\hline Brazil & 275,576 & 680,948 \\
\hline Bulgaria & 500 & 1,235 \\
\hline Cameroon & 2,500 & 6,177 \\
\hline Canada & 430,600 & $1,064,012$ \\
\hline Chile & 273,000 & 674,583 \\
\hline China & 301,295 & 744,490 \\
\hline Colombia & 30,000 & 74,130 \\
\hline Costa Rica & 8,974 & 22,174 \\
\hline Croatia & 120 & 296 \\
\hline Cuba & 8,495 & 20,991 \\
\hline Cyprus & 52 & 128 \\
\hline Czech Republic & 218,114 & 538,959 \\
\hline Denmark & 174,600 & 431,436 \\
\hline Dominican Republic & 14,963 & 36,973 \\
\hline Ecuador & 60,000 & 148,260 \\
\hline Egypt & 15,000 & 37,065 \\
\hline El Salvador & 4,900 & 12,107 \\
\hline Estland & 20,141 & 49,768 \\
\hline Fiji & 200 & 494 \\
\hline Finland & 147.943 & 365.567 \\
\hline France & 419,750 & $1,037,202$ \\
\hline Germany & 632,165 & $1,562,079$ \\
\hline Ghana & 5,453 & 13,474 \\
\hline Greece & 31,118 & 76,892 \\
\hline Guatemala & 14,746 & 36,437 \\
\hline Guyana & 425 & 1,050 \\
\hline Honduras & 1,769 & 4,371 \\
\hline Hungary & 105,000 & 259,455 \\
\hline Iceland & 5,466 & 13,056 \\
\hline India & 41,000 & 101,311 \\
\hline Indonesia & 40,000 & 98,840 \\
\hline Ireland & 30,070 & 74,302 \\
\hline Israel & 7,000 & 17,297 \\
\hline Italy & $1,230,000$ & $3,039,330$ \\
\hline Jamaica & 205 & 506 \\
\hline Japan & 5,083 & 12,560 \\
\hline Kenya & 494 & 1,220 \\
\hline Laos & 150 & 370 \\
\hline
\end{tabular}


Table 3. Land area under organic management (SOEL-Survey, February 2003).

\begin{tabular}{|c|c|c|}
\hline Country & Organic Hectares & Organic Acres \\
\hline Latvia & 20,000 & 49,420 \\
\hline Lebanon & 250 & 617 \\
\hline Liechtenstein & 690 & 1,704 \\
\hline Lithuania & 6,769 & 16,726 \\
\hline Luxembourg & 2,141 & 5,290 \\
\hline Madagascar & 1,230 & 3,039 \\
\hline Malawi & 298 & 736 \\
\hline Malaysia & 131 & 323 \\
\hline Mauritius & 175 & 432 \\
\hline Mexico & 143,154 & 353,733 \\
\hline Morocco & 11,956 & 29,543 \\
\hline Nepal & 45 & 111 \\
\hline Netherlands & 38,000 & 93,898 \\
\hline New Zealand & 63,438 & 156,755 \\
\hline Nicaragua & 7,000 & 17,297 \\
\hline Norway & 26,673 & 65,908 \\
\hline Pakistan & 2,009 & 4,964 \\
\hline Panama & 5,111 & 12,629 \\
\hline Papua New Guinea & 4,265 & 10,538 \\
\hline Paraguay & 61,566 & 152,129 \\
\hline Peru & 84,908 & 209,807 \\
\hline Philippines & 2,000 & 4,942 \\
\hline Poland & 44,886 & 110,913 \\
\hline Portugal & 70,857 & 175,087 \\
\hline Republic of Korea & 902 & 2,228 \\
\hline Romania & 18,690 & 46,182 \\
\hline Russia & 5,276 & 13,036 \\
\hline Senegal & 2.500 & 6.177 \\
\hline Slovakia & 58,706 & 145,062 \\
\hline Slovenia & 5,280 & 13,046 \\
\hline South Africa & 45,000 & 111,195 \\
\hline Spain & 485,079 & $1,198,630$ \\
\hline Sri Lanka & 15,125 & 37,596 \\
\hline Suriname & 250 & 617 \\
\hline Sweden & 193,611 & 478,412 \\
\hline Switzerland & 102,999 & 254,510 \\
\hline Syria & 74 & 182 \\
\hline Tanzania & 5,155 & 12,738 \\
\hline Thailand & 3,429 & 8,473 \\
\hline Tunisia & 18,255 & 45,108 \\
\hline Turkey & 57,001 & 140,849 \\
\hline Uganda & 122,000 & 301,462 \\
\hline Ukraine & 164,449 & 406,353 \\
\hline United Kingdom & 679,631 & $1,679,369$ \\
\hline Uruguay & 678,481 & $1,676,526$ \\
\hline USA & 950,000 & $2,347,450$ \\
\hline Vietnam & 2 & 5 \\
\hline
\end{tabular}


Table 3. Land area under organic management (SOEL-Survey, February 2003).

\begin{tabular}{||l|c|c||}
\hline \hline Country & Organic Hectares & Organic Acres \\
\hline Yugoslavia & 15,200 & 37,559 \\
\hline Zambia & 5,688 & 14,055 \\
\hline Zimbabwe & 40 & 98 \\
\hline SUM & $22,811,267$ & $56,366,640$ \\
\hline $\begin{array}{l}\text { The World of Organic Agriculture 2003 - Statistics and Future Prospects } \\
\text { http://www.soel.de/inhalte/publikationen/s/s_74.pdf }\end{array}$ & \\
\hline \hline
\end{tabular}

